\title{
The Real Estate Business in Dhaka City: Growth and Contribution to the Economy of Bangladesh.
}

\author{
Md. Mohiuddin \\ Associate Professor, Department of Management Studies Jagannath University, Dhaka-1100, Bangladesh.
}

\begin{abstract}
Real estate business is a growing business in Bangladesh. Urbanization is taking place very fast; the real estate business is also becoming more significant business in the last two decades. Dhaka city is one of the most densely populated cities of the World. So population is increasing tremendously but land is fixed. The role of real estate companies is very much important to manage this. As the competition is growing, a company needs to focus on more the unique values that can help a company to survive in the long run. Backward linkage industries are also flourishing for the growth of real estate business. This business sector contributes a large amount to GDP, employment generation \& mitigating housing problem. This study is to find out the current scenario of real estate business with findings, concluding \& recommendations. This work focuses on the growth and contribution of real estate business in Dhaka city.
\end{abstract}

Keywords: Real estate business, Growth of real estate, Contribution to GDP, Real estate in Dhaka City.

\section{Introduction}

Dhaka is the most important and capital city of Bangladesh where every year people are increasing. The population of Dhaka City is increasing terrifyingly, current population growth of Bangladesh is $2.06 \%$ but the population growth of Dhaka City is $4.2 \%$, its share of national urban population was $25 \%$ in $1981,31 \%$ in 1991 and $34 \%$ in 2001 respectively. So it is very clear that housing problems is acute beside the increasing population. Real estate is playing an important role to solve the housing problem and contribution to the economy. Real estate business is also becoming more significant business in the last couple of years. The business of real estate is the profession of buying, selling or renting land, building or housing. Three decades back the dwellers were reluctant to live in flats in Dhaka city, as mentioned earlier the main reason is economic due to increased land cost as well as construction cost and other reasons such as reluctance of individuals to spend time and energy in house construction, increased awareness of apartment living and western influence. As a result apartment-owing is becoming increasingly popular and demand. Many apartment builders have appeared in the market in recent years. Twenty years ago there were fewer than five companies in Bangladesh engaged in developing apartments while today there are more than 2000 developers. It may be mentioned here that in 1988 there were less than20 such developers in Dhaka, now-a-days 1500 \& above developers are working in Dhaka City among them 1226 developers are members of Real Estate \& Housing Association of Bangladesh (REHAB). Nevertheless, there are many other companies/ individuals engaged in such development in smaller scale and selling apartments to friends and relatives only. With a rising population and increasing housing demand, apartment culture has grown up in Dhaka. It first appeared in Dhaka near Central Road and subsequently the city experienced a boom in apartment development in all residential areas including Paribagh, Moghbazar, Seddeshwari, Shantinogor, Dhanmondi, Mirpur, Banani, Old DOHS, Gulsan, Baridhara \& Uttara to name just a few in line with this. During the last decade, the total volume of real estate, renting and business service sector increased every year which implies a positive growth in the sector every year which implies a positive growth in the sector but compared to overall GDP growth this sector expanded at a slower rate. The growth in this industry also faciliated a fast growth in many linkage industries like glass \& glass products industry, brick industry, cement industry, ceramic industry, iron and steel industry etc over the last decade. Such consistent growth in the real estate sector is mainly due to a consistent demand at the consumer end.

\section{Objectives}

Real estate is a profitable business in Dhaka City and citizen are highly interested to purchase a flat/apartment for solving the housing problem. In Dhaka City, where population has been increasing without any potential stop sign, need for housing development has got more importance in recent past. The specific objective is to find out the role and contribution of real estate business to meet the housing needs in the Dhaka City. Other objective is to get an explicable thought regarding the real estate industry in Dhaka city.

\section{Methodology}

Data have been collected from both primary and secondary sources but maximally from secondary source. The primary data collection methods were observation, interview \& questionnaire. Primary data have 
collected from Real Estate \& Housing Association of Bangladesh (REHAB) members. Different publications of REHAB, journals, magazines and websites were used in collecting data from the secondary source. Statistical different techniques are used for analyzing data.

\section{Urbanization And Population In Dhaka City}

During the last decades, metropolitan Dhaka has recorded a phenomenal growth in terms of population and area. At present Dhaka is one of the fastest growing metropolises in the World, after the War of Independence of 1971, the Capital city and its population increased manifold in the subsequent decades. The land area and population of Dhaka city is usually expressed in terms of two boundaries. One is Dhaka City Corporation (DCC) boundary and the other one is the larger boundary of Rajdhani Unnayan Kartipakkhya (RAJUK). Within DCC limits ( with about 520 sq.kilom./200sq.miles.), there are already over 7 million people and growing possibly at 5.5\% annually. Gross density is $11570-13500$ persons per square kilometer. In some parts density of over 38,580 persons per square kilometer exist, with an average of 3 stories for pucca development or one story for kutcha development. But at such high densities, residents do not get enough road space or open space or other non-residential space either. Outside DCC, but within RAJUK limits, there are 1008 sq.kilo.ms wherein live another 2 to 3 million people.

Table 1: Urbanization in Bangladesh and Urban Population growth of Dhaka city

\begin{tabular}{|c|c|c|c|c|c|}
\hline \multirow[t]{2}{*}{ Year } & \multirow{2}{*}{$\begin{array}{l}\text { Total Urban } \\
\text { Population }\end{array}$} & \multirow{2}{*}{$\begin{array}{c}\text { Total Population of } \\
\text { Dhaka city }\end{array}$} & \multirow{2}{*}{$\begin{array}{c}\text { Percentage of Urban } \\
\text { population }\end{array}$} & \multicolumn{2}{|c|}{ Annual Growth Rate (\%) } \\
\hline & & & & All Urban area & Dhaka City \\
\hline 1961 & 2640726 & 718766 & 5.19 & 3.75 & 5.74 \\
\hline 1974 & 6273602 & 2068353 & 8.78 & 6.62 & 8.47 \\
\hline 1981 & 13535963 & 3440147 & 15.54 & 10.63 & 7.53 \\
\hline
\end{tabular}

Source:( BBS-1997 \&BBS-2001)

At present the Dhaka metropolitan area consists of the inner city which is almost built up and surrounding areas which are semi-built up. During the period from 1981 to 2000, the greater Dhaka population grew at an average rate of $5.5 \%$ from about 3.44 million to 10.0 million. During the same period the built up area increased from 104 sq. $\mathrm{km}(39 \%$ of the city area) to 150 sq.km(55\%). By the year 2015 the expected population of the city is forecasted to be as high as 15.7 million. It is expected that Dhaka will become one of the ten largest cities of the World by the year 2020 with a population as high as 20 million and to make provision for accommodation and comfortable living of this large population, creation of new satellite towns adjacent to the city and also new towns around the cosmopolitan city will be necessary.

\section{Reasons For Real Estate Business In Dhaka City}

The main reasons for the development of real estate business in Dhaka city are:

- Rapid increase population in the city.

- Scarcity of unoccupied lands in important parts of the city.

- Very high price of land.

- Hazards involving purchase of land.

- Profit motives of land owners.

- Increase of remittance inflows in that finance many purchase of flat/apartment.

- Re-structuring of households to single family units

- Standard of security and other services in apartments.

\section{Growth \& Contribution Of The Real Estate Bussiness}

In the last four decades private developers have supplied more than 1, 00,000 units of apartments to the Dhaka city and will be supplying 25000 more units in the next three years. The business of real estate had very slow growth rate in the first decade. The industry grew in a moderate pace since 2006 , but between 2008 and 2010 the growth rate was exponential. Total volume of real estate, renting \& business services and GDP contribution trend analysis are given below: 
Table-2: Growth, GDP Contribution Trend Analysis \& Total Volume of Real Estate Business.

\begin{tabular}{|c|c|c|c|}
\hline Year & Total volume( Crore Taka) & GDP Contribution(\%) & Growth (\%) \\
\hline $2001-02$ & 19440 & 8.63 & - \\
\hline $02-03$ & 20106 & 8.48 & 3.43 \\
\hline $03-04$ & 20913 & 8.30 & 4.01 \\
\hline $04-05$ & 21678 & 8.12 & 3.66 \\
\hline $05-06$ & 22404 & 7.87 & 3.35 \\
\hline $06-07$ & 23147 & 7.64 & 3.32 \\
\hline $07-08$ & 24097 & 7.49 & 4.11 \\
\hline $08-09$ & 24970 & 7.34 & 3.62 \\
\hline $09-10$ & 25981 & 7.20 & 4.05 \\
\hline
\end{tabular}

Source: Statistical Year Book of Bangladesh-2010

Employment Generation: The real estate sector is at present creating employment for about 01 Million people who are directly \& indirectly involved in the sector. According to Labor Force Statistics- in 1999-2000, 2.1\% of the labor force was engaged in construction whereas for 1995-1996 the figure was $1.8 \%$. These figures include workers engaged in brick chipping and working in delivery trucks, engineers and architects. 5000 engineers \& 6000 management staff are engaged in this sector.

Linkage Contribution: The real estate sector has also made substantial contributions to the growth of a host of backward and forward linkage sectors which include paints, ceramics, aluminum, furniture, consultancy and many others. In this context, this business provided examples of catalytic influence of the real estate and housing sector in development of linkage industries whereby the sector is immensely contributing to employment and GDP. It is to be mentioned that Bangladeshi State-of-the-art ceramic industries largely meeting the local demand for ceramics, Thai and Kai aluminum meeting demand for door and window frames, more than a dozen paint industries, many of them multinationals are creating to local demand, a large number of furniture making and interior design companies supporting the housing industry and exponentially growing cement sector which is helping the country to attain self-sufficiency in this important input.

\section{Conclusion}

The growth of housing in Dhaka city is really going fast now. But the barrier of the real estate growth is for its scarcity of resources and high prices. Lack of infrastructural facility is another main obstacle for the land developers to expand real estate business. The land developers do not get convenient land of large size from one single owner for abstaining from the legal problems and the higher carrying cost of materials for building the flat. In spite of barriers of real estate business, this business is expanding day by day in Dhaka city. The various steps have been taken for developers \& buyers such as bank loan facilities, Govt. should reduce the VAT \& income tax. It is noted that the importance of the sector can hardly be overemphasized. Provision of new incentives in the last fiscal budget indicates that government is well aware of the problems in this sector. This business makes a significant contribution to the GDP and is generating substantial employment opportunities and facilitating the growth of linkage industries. Bangladesh will encounter high levels of urbanization by 2015 and by that time Dhaka will need to house about tow crores people to become the fifth largest city in the World. So mitigating of this huge demand requires a long-term plan to be formulated that a collective effort from both the private sector \& individual developers may sufficiently provide for the huge demand.

\section{References}

[1]. Leo Yaskar Dewri, A Comprehensive Study on the Real Estate Sector of Bangladesh, REHAB, July, 2012.

[2]. R. Afsar, Towards Organising the Urban poor( Dhaka: Bangladesh Institute of Development Studies),1988.

[3]. Asian Development Bank (ADB), Government of Bangladesh (GOB), Study of Urban Poverty in Bangladesh (Dhaka: Planning Commission, Government of Bangladesh), 1996.

[4]. Asian Development Bank(ADB),Economic Development Institute (EDI), The Urban Poor and Basic Infrastructure Services in AsiaPacific, Manila,1991.

[5]. M. Seraj \& Dr.Toffiq, Prospects of Private Housing and Future Action, REHAB Week-2007, Westin Hotel, Dhaka, 19 November,2009.

[6]. Mahbubur Rahman, Apartment for All: Cutting Superfluous Costs, The Daily Star, Dhaka, 05 July, 2010.

[7]. Jamil, Gazi Mohammad Hasan, \& Mosabbir Ahmed, Housing for Low Income People in Bangladesh: Problems and Prospects, Dhaka, 19 November, 2009.

[8]. A.Hossain, Some Aspects of Real Estate Business in Dhaka City, The New Nation, 14 May, 2001.

[9]. T.M.Seraj, Solving Housing Problem Through Private Sector Real Estate Development in Dhaka, Architecture and Construction (Urban Development Volume 10), Quality Offset Press, Dhaka,2003.

[10]. www.Rehab.bd.com

[11]. www.edgehill.ac.uk

[12]. www.unhabitat.org. 